\title{
Double Standards of International Recognition: Right vs. Might?
}

\author{
Daria V. Isachenko
}

https://doi.org/10.46272/2587-8476-2020-11-3-22-34

\begin{abstract}
Why do some states get recognized, while others are denied the privilege? This article examines the underlying logic behind the contingency and inconsistency in the application of statehood standards to unrecognized, de facto states. When it comes to the practice of state recognition, the article argues, it is not merely a question of Great Power politics. Nor is it a question of whether a state has earned sovereignty and thus has a legally rightful claim to international recognition. Instead, the norms of state recognition can be better understood as a reflection of the balance of powers in the international order, rather than being a guiding principle for assessing claims to statehood. Central to this balance is the question of whether right corresponds with might and vice versa. If such a balance is absent, we observe what are considered to be double standards in the practice of international recognition. The theoretical framework draws on Baruch Spinoza's idea of right being coextensive with power. Based on this assumption, the article demonstrates that the problem is not the incoherence of norms regulating international recognition, but rather the absence of a necessary equilibrium between might and right to ensure the universal applicability of those norms. The argument is illustrated through a comparison of the right to self-determination

that was granted to peoples in former colonies during the Cold War period and the US-led recognition of Kosovo, followed by Russia's recognition of South Ossetia and Abkhazia in 2008. The article shows that the practice of international recognition is conditional on global responses to particular concerns and circumstances. It is thus contingent on the degree to which powers agree as to how to address these concerns. The key suggestion put forward in the article is that, ultimately, there is no significant conceptual difference between the Declaration on the Granting of Independence to Colonial Countries and Peoples that marked the shift from the achievement of effective statehood to eventual independence and the 2008 wave of recognitions for non-colonial cases. Both show that norms and their enforcement depend on the same logic of right and power being mutually constitutive.
\end{abstract}

\section{KEYWORDS}

State recognition, double standards, international order, de facto states, unrecognized states 
Newcomers are always viewed with suspicion. Especially if these newcomers are aspiring states that seek to challenge the well-established inter-state system of international relations based on the sanctified doctrine of territorial integrity. Seen as separatists upsetting the international order, they nevertheless embark upon statebuilding projects, creating all the necessary institutions and normative discourses to buttress their quest for independence and, equally importantly, for international recognition. As aspiring states strive for outside support of their claims to statehood, the international community remains for the most part reluctant and even hostile to these requests. The way of dealing with such de facto, unrecognized states has been to either ignore them or actively oppose them. ${ }^{1}$ The option of acceptance is rarely used, since it might disturb the existing system of sovereign states by prompting additional secessions. Yet, as the case of Kosovo (as well as those of Abkhazia and South Ossetia) illustrates, exceptions can indeed be made.

Why do some states eventually get recognized, while others are denied the privilege? How many states need to recognize the newcomer for it not be considered a de facto, contested, unrecognized, informal, emerging state any more by the scholarly community? ${ }^{2}$ Does the quantity and/or the weight of states in the global arena that bestow recognition matter $?^{3}$ Or is the ultimate indicator of international acceptance equal a membership in the United Nations? Do the criteria for statehood play a role in the assessment of claims to legitimacy? Or is it all about power politics? As the cases of Kosovo, Abkhazia and South Ossetia, as well as those of Northern Cyprus and Transdniestria demonstrate, there is no straightforward answer to these questions. The only point of agreement among scholars is that the application of norms regulating international recognition has been incoherent and inconsistent. ${ }^{4}$ And if the authorities of unrecognized states "were to ask what they have to do in order to be able to establish a juridically sovereign state with subject status under international law, the lawyers and scholars have nothing to say but to refer them to the brutal contingencies of international relations or the unpredictable caprices of great power politics." ${ }^{5}$

The debate on the practice of state recognition concerns both international law and the nature of global politics. The legal position for non-colonial cases has been succinctly formulated by Buchanan, "the consensus among legal scholars at this time is that international law does not recognize a right to secede in other circumstances, but that it does not unequivocally prohibit it either." ${ }^{16}$ As such, the practice of international recognition is often considered to be exclusively determined by Great Powers. ${ }^{7}$ The cases of Kosovo, Abkhazia, and South Ossetia appeared to confirm the dominant role of power politics. Furthermore, the wave of recognitions in 2008 also raised such questions about what the right to self-determination means for other unrecognized,

1 Pegg 1998, 181.

2 For the terms, see Pegg 1998; Geldenhuys 2009; Caspersen 2012; Isachenko 2012; Visoka 2018, respectively. For a detailed overview of the current research on de facto states, see Broers 2015 as well as Dembinska, Campana 2017.

3 The diplomatic relations of states lacking universal recognition is a relatively new, but expanding field of research. For a case study of Kosovo, see Visoka 2018; for Abkhazia and South Ossetia, see Ó Beacháin 2020; for Transdniestria and Northern Cyprus, see Isachenko 2020; and for other cases, consult Visoka et al. 2020.

4 For a comprehensive overview of theoretical and normative perspectives, as well as the actors, forms and practices of international recognition, see Visoka et al. 2020.

5 Kurtulus 2005, 190.

6 Buchanan 1997, 33.

7 Fabry 2010; Coggins 2014. 
de facto states that are not deemed exceptional enough and whether they would now be likely to adjust their strategies in seeking international recognition. ${ }^{1}$ Equally important is the fact that the highly political nature of the wave of recognitions in 2008 has also been considered a signal of "a possible shift away from international consensus for the recognition of new states" and may be "driven, or exacerbated, by changes in the international order." 2 The primary interest of this article is also to assess the interrelation between state recognition and international order. Examining the logic behind the contingency and inconsistency in the application of statehood standards to unrecognized states, the key contribution of this article is to demonstrate the pattern that lies behind not only exceptional cases, but also behind the evolution of the norms and practice of international recognition as a whole.

When it comes to the practice of state recognition, the article argues, it is not merely a question of Great Power politics. Nor is it a question of whether a state has earned sovereignty and thus has a legally rightful claim to international recognition. Instead, the norms of state recognition and their application can be better understood as a reflection of the balance of powers in the international order, rather than being a guiding principle for assessing claims to statehood. Central to this balance is the question whether right corresponds with might and vice versa. If such a balance is absent, we observe what are considered to be double standards in the practice of international recognition. By implication, a contestation of the right to make an exception simultaneously presents a challenge of the might to do so.

The most telling examples here are the Western-led recognition of Kosovo and Russia's recognition of Abkhazia and South Ossetia in 2008. The problem is thus not the incoherence of norms regulating international recognition, but rather the discrepancy between might and right to impose these norms. In cases when right and might are more or less aligned, we observe the establishment of norms that have historically gone practically uncontested. A prominent example in this is the selfdetermination principle in relation to former colonies.

The theoretical framework of this article is based on an assumption borrowed from B. Spinoza, namely his idea that right is coextensive with power. ${ }^{3}$ This perspective displaces the opposition between might and right in two traditions of international relations theories. It is not only a question of Realpolitik as suggested in the Machiavellian tradition, according to which the only thing that matters is the idea of reason of State and that relations between states are determined by power. ${ }^{4}$ What is more, international relations are not only about the primacy of right, which is argued in the Grotian tradition. ${ }^{5}$ It is thus not a matter of "right vs. might." Rather, it is a matter of "right and might," because "the right of each thing extends as far as its power does." In other words, "what we can do, we may do."7

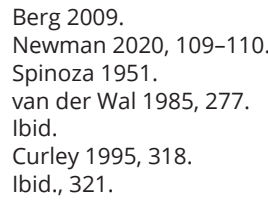


As this article aims to demonstrate, the idea of right being coextensive with power or, more specifically, the imbalance between right and power can also shed light on the emergence of double standards in the contemporary practice of international recognition. The argument is illustrated in two parts. First, the article considers the historicity of international recognition by showing how the norms of international recognition have evolved over time. In particular, it focuses on the establishment of the right of self-determination for peoples in former colonies during the Cold War period. By problematizing the binary between legal norms and power politics, the aim is to illustrate how changes in international responses to recognition that are taken as a given today have served a particular political purpose in the international order. Second, the article examines the US-led recognition of Kosovo and Russia's recognition of South Ossetia and Abkhazia in 2008. These exceptional cases have intensified the debate on the rules and norms of international recognition, with the main area of contention being whether international law matters at all, or whether claims to statehood are inevitably confined to the expediency of geopolitical considerations of Great Power politics. In conclusion, the article compares the norms of selfdetermination for peoples in former colonies with the exceptional recognitions of Kosovo, South Ossetia, and Abkhazia by arguing that they reflect the same logic of right and power being mutually constitutive. The perception of double standards can thus be viewed as a result of the discrepancy between right and might.

\section{The Historicity of International Recognition}

The formal requirements of statehood that are taken today as a universal reference point for legitimizing the validity of claims to statehood were laid down in the Montevideo Convention on the Rights and Duties of States (1933). ${ }^{1}$ According to the Convention, a state as a subject of international law should possess the following qualifications: "a permanent population, a defined territory, a government capable of maintaining effective control over its territory and of conducting international relations with other states." ${ }^{2}$ However, there is a wide divergence between the empirical and juridical attributes of statehood. In practice, empirical statehood does not necessarily result in recognition, as in the case of unrecognized de facto states. Moreover, recognition has even been bestowed in spite of a lack of effective control over the territory, as in the case of recognized quasi-states. ${ }^{3}$ Viewed from outside, these are indeed states. That is, they enjoy international status as states and are recognized as such by the international community, but they fail to prove that they exercise effective control over their territory. The international recognition of quasi-states without effective control must seem especially unfair for the authorities of unrecognized de facto states. In addition to the criteria for statehood set out in the Montevideo Convention, they must now also persuade the international community that their emergence was

1 See, for instance, self-depiction of Transdniestria (the Pridnestrovian Moldavian Republic) on the website of its Ministry of Foreign Affairs that follows the logic of the Montevideo Convention: it outlines a defined territory and population and emphasizes the functioning of institutions and its foreign policy activities. "Country Overview," Ministry of Foreign Affairs of Pridnestrovian Moldovan Republic, accessed October 20, 2020, http://mfa-pmr.org/en/about_republic.

2 Evans, Newnham 1998, 512.

3 Jackson 1994. 
a result of the principle of self-determination and that their institutions are not only functioning, but that they do so in a democratic way. How can we explain the double standards in the statehood requirements for de facto states and quasi-states? Equally important, how did self-determination and democracy become the essential features for assessing the legitimacy of claims to independence?

The principle of self-determination of peoples that is often invoked by sub-state groups striving for international recognition is a context-specific product of the United Nations. It was meant as a global response to particular historical circumstances. Although its elaboration had a more or less universal character, its applicability was exclusively limited to former colonial territories. The general guiding rule has been that, "Empires should be broken up, but the successor nation-states should be preserved intact, irrespective of the national complexity they might contain." 1 Selfdetermination as a norm and its importance for former colonies, however, meant that requirements of empirical statehood such as effective government were discarded. Thus, in the $19^{\text {th }}$ century, the criteria for internal effective (i.e. de facto) statehood was an overarching principle that lead to eventual recognition as a state by others. But this ceased to be a necessary precondition after World War II. Instead, the decisive element has become a right of self-determination of peoples seeking liberation from colonial centers. As pointed out by M. Fabry, "the shift in the understanding of selfdetermination from the moral and negative right to seek independence by a selfidentified political community to the legal and positive entitlement to independence allotted by international society to particular entities reflected the global political revolution" of the 1950s. ${ }^{3}$ The rationale behind such a tectonic change was to "cast off the institution of colonialism and the underlying hierarchical division into 'civilized' peoples suitable for statehood and less than fully civilized ones excluded from it."4

The pivotal document that solidified the right of self-determination for peoples in the former colonies was UN General Assembly Resolution 1514, also known as the Declaration on the Granting of Independence to Colonial Countries and Peoples, adopted in 1960. The resolution stipulated the entitlement to independence as follows: "All peoples have the right to self-determination; by virtue of that right they freely determine their political status and freely pursue their economic, social and cultural development." It rendered the previous prerequisites for effective statehood illegitimate for colonial territories striving for independence by emphasizing that the "inadequacy of political, economic, social or educational preparedness should never serve as a pretext for delaying independence." ${ }^{6}$ In addition to authorizing the new entitlement to self-determination, the resolution affirmed that "any attempt aimed at the partial or total disruption of the national unity and the territorial integrity of a country is incompatible with the purposes and principles of the Charter of the United Nations." ${ }^{17}$ The insistence on the principle of territorial integrity meant

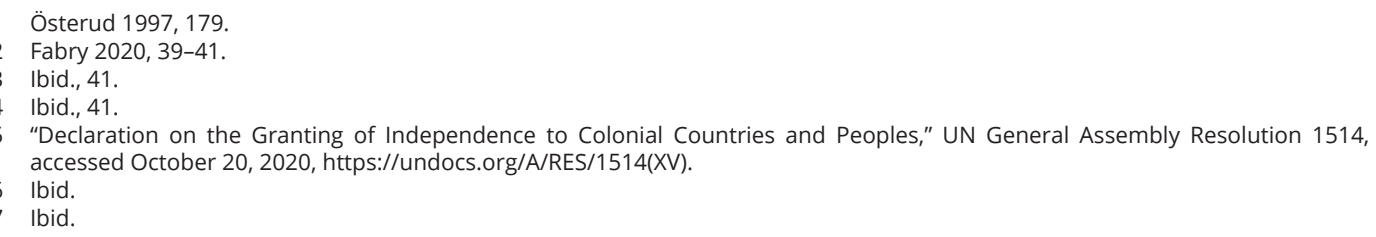


that other claims to self-determination were not to be considered in the non-colonial setting. The resolution was endorsed by 89 UN member states. No member state voted against it, although nine members opted to abstain, eight of which were colonial powers. ${ }^{1}$ The anti-colonial resolution thus reflected a new power balance in the international order during the Cold War, with the then Third World camp claiming victory. Importantly, where the Third World representatives were themselves involved, as for instance in the cases of Morocco's and Mauritania's claims in Western Sahara and Indonesia's claims in East Timor, the right to self-determination remained suspended. ${ }^{2}$

The struggle against colonialism during the Cold War era thus cast aside the requirements of effective statehood by instituting the right to independence for former colonial territories. Following the end of the Cold War, the criteria for statehood were further refined and adjusted to the new political circumstances. To address the dissolution of the Soviet Union and the Socialist Federal Republic of Yugoslavia, the European Community announced the Declaration on the Guidelines on the Recognition of New States in Eastern Europe and in the Soviet Union on 23 December 1991. Even though the right of self-determination had previously been reserved for the colonial context, it formed an essential principle in the European Community document. Most importantly, the European Community underlined the demand for the new states "to constitute themselves on a democratic basis" and to demonstrate "respect for human rights and minority rights as well." ${ }^{3}$ The US, on the other hand, was less specific about the normative preferences guiding its policy for recognizing new states that emerged from the former Yugoslavia, with then US president George Bush simply announcing that "the United States recognizes Bosnia and Herzegovina, Croatia and Slovenia as sovereign and independent states [...] We take this step because we are satisfied that these states meet the requisite criteria for recognition." ${ }^{4}$ The US did go into more detail when Kosovo declared independence in February 2008. However, as the next section illustrates, it did not add much clarity as far as legal norms are concerned - although it did reflect the lack of global consensus and the discrepancy between right and might in the international community.

\section{How to Earn Recognition in the Contemporary World Order}

When the authorities of Northern Cyprus announced its unilateral declaration of independence on 15 November 1983, it was regarded as illegal by the international community. The establishment of the Turkish Republic of Northern Cyprus was followed by UN Security Council Resolution 541 on 18 November 1983, which pronounced the attempt the create this entity "invalid" and called "upon all States not to recognise any Cypriot state other than the Republic of Cyprus." In yet another UN Resolution 550 dated 11 May 1984, the international community was "gravely concerned about

1 Countries that abstained included Portugal, Spain, the Union of South Africa, the United Kingdom of Great Britain and Northern Ireland, the United States of America, Australia, Belgium, the Dominican Republic and France. See "General Assembly, 15 th session: 947th plenary meeting, Wednesday, December 14, 1960, New York," United Nations, accessed October 20, 2020, https://digitallibrary.un.org/record/747044?In=en.

2 Gunter 1979.

3 Ryngaert, Sobrie 2011, 475.

4 Ibid., 477. 
the further secessionist acts in the occupied part of the Republic of Cyprus," more specifically about "the purported exchange of ambassadors between Turkey and the legally invalid 'Turkish Republic of Northern Cyprus' and the contemplated holding of a 'constitutional referendum' and 'elections,' as well as by other actions or threats of actions aimed at further consolidating the purported independent State and the division of Cyprus." Turkey remains the only country that recognizes Northern Cyprus, and Turkish Cypriot institutions and practices continue to be accompanied by inverted commas, as well as "by adjectives and adverbs like 'the purported,' 'the socalled,' 'the pseudo,' 'the invalid,' and 'the illegal,' all putting the existence of the political entity of northern Cyprus into doubt." Importantly, non-recognition does not only exclude entities that are bound to remain de facto states from having diplomatic and economic relations, but also implies a certain humiliation: "the use of quotation marks differentiates those who merely self-proclaimed to be sovereign, and thus from the perspective of foreign authorities feign statehood, from those who in the same eyes have actually been accepted as sovereign." ${ }^{2}$

When Kosovo declared its independence in 2008, the UN General Assembly passed a resolution (proposed by Serbia) to ask the International Court of Justice (ICJ) to assess the legality of the declaration. More specifically, the ICJ was requested to provide an advisory opinion on the following question: "Is the unilateral declaration of independence by the Provisional Institutions of Self-Government of Kosovo in accordance with international law?"3 As the Serbian side argued, "the question posed is amply clear and refrains from taking political positions on the Kosovo issue." ${ }^{4}$ Furthermore, in the view of Serbia, this "would prevent the Kosovo crisis from serving as a deeply problematic precedent in any part of the globe where secessionist ambitions are harboured." ${ }^{5}$ The US representative was, however, of the opinion that this was "unnecessary and unhelpful," urging all other UN members states "to consider the potential consequences of asking the Court to opine on the matter, as doing so might open the door for others to seize on language to bolster their own claims for independence." ${ }^{\prime 6}$ The UN General Assembly resolution to seek advice of ICJ was finally adopted with 77 votes in favour, 74 abstentions, and six votes against (on the part of Albania, the Marshall Islands, the Federated States of Micronesia, Nauru, Palau, and the United States). ${ }^{7}$

Like the question addressed to the ICJ, the latter's approach to the issue was cautiously clear. In the advisory opinion that was eventually issued in June 2010, the ICJ evaluated the question as sufficiently "narrow and specific" in that it asks the Courts opinion on "whether or not the declaration of independence is in accordance with international law." As such, the Court was not asked "about the legal consequences of that declaration" or "about the validity or legal effects of the recognition of Kosovo

1 Navaro-Yashin 2003, 75.

2 Fabry 2010, 7.

3 "Accordance with International Law of the Unilateral Declaration of Independence in Respect of Kosovo," ICJ, Advisory Opinion, July 22, 2010, accessed October 20, 2020, https://icj-cij.org/public/files/case-related/141/141-20100722-ADV-01-00-EN.pdf.

4 "Backing request of Serbia, General Assembly decides to seek International Court of Justice Ruling on Legality of Kosovo's Independence," UN, accessed October 20, 2020, https://www.un.org/press/en/2008/ga10764.doc.htm. 
by those States which have recognized it as an independent State." The Court was also aware that it was not requested to assess "whether or not Kosovo has achieved statehood." Accordingly, the ICJ came to the following conclusion: "General international law contains no applicable prohibition of declarations of independence [...] the declaration of independence of 17 February 2008 did not violate general international law."2 As the Court reasoned:

During the eighteenth, nineteenth and early twentieth centuries, there were numerous instances of declarations of independence, often strenuously opposed by the State from which independence was being declared. Sometimes a declaration resulted in the creation of a new State, at others it did not. In no case, however, does the practice of States as a whole suggest that the act of promulgating the declaration was regarded as contrary to international law. ${ }^{3}$

As far as the contested status of Kosovo as a state on the international arena after its declaration of independence is concerned, the advisory opinion of the ICJ did not add the much desired clarification. However, Kosovo has been recognized by a far greater number of countries than other states that do not enjoy UN membership. According to the Kosovan authorities, 114 out of the 193 UN member states recognize Kosovo as an independent country, "thereby, fulfilling the initial aim of obtaining more than 100 recognitions." 4 Serbia, on the other hand, pursues the objective of "having half of UN member states not recognising its former province's independence." ${ }^{\prime 5}$ According to Serbia's most recent calculations, 18 countries have already changed their decisions with the actual number of recognitions now below 100. In March 2020, the government of Sierra Leone, being the $18^{\text {th }}$ state to renounce its recognition of Kosovo, shared with Serbia its "considered view that any recognition it had conferred (expressly or by necessary implication) on the independence of Kosovo may have been premature." ${ }^{6}$ What does this score tell us about the significance of the criteria for statehood and, equally importantly, about the power constellation of the contemporary world order?

As the Kosovo leadership clearly and unequivocally acknowledged, "American support in our external and internal affairs has been one of the basic preconditions for a successful statebuilding process." Indeed, the US and other Western countries have made an essential contribution, especially with regard to the question of how

1 "Accordance with International Law of the Unilateral Declaration of Independence in Respect of Kosovo," ICJ, Advisory Opinion, July 22, 2010, accessed October 20, 2020, https://icj-cij.org/public/files/case-related/141/141-20100722-ADV-01-00-EN.pdf.

2 Ibid.

3 Ibid.

4 "Website of Kosovo's Ministry of Foreign Affairs," accessed October 20, 2020, https://www.mfa-ks.net/en/politika/483/njohjetndrkombtare-t-republiks-s-kosovs/483.

5 Agata Palickova, "15 countries, and counting, revoke recognition of Kosovo, Serbia says," EURACTIV, August 27, 2019, accessed October 20, 2020, https://www.euractiv.com/section/enlargement/news/15-countries-and-counting-revoke-recognition-ofkosovo-serbia-says/.

6 "Serbia Claims Sierra Leone is Latest Country to Rescind Kosovo Recognition," RFE/RL's Balkan Service, March 3, 2020, accessed October 20, 2020, https://www.rferl.org/a/serbia-claims-sierra-leone-is-latest-country-to-rescind-kosovorecognition/30466817.html.

7 Visoka 2020, 411. 
to legitimize Kosovo's self-determination in a non-colonial context without the consent of the host state, Serbia. As then the US Secretary of State C. Rice emphasized:

The unusual combination of factors found in the Kosovo situation - including the context of Yugoslavia's breakup, the history of ethnic cleansing and crimes against civilians in Kosovo, and the extended period of UN administration are not found elsewhere and therefore make Kosovo a special case. Kosovo cannot be seen as a precedent for any other situation in the world today. ${ }^{1}$

On 26 August 2008, Russia recognized Abkhazia and South Ossetia as independent sovereign states following its brief war with Georgia. Ultimately, as observed by M. Fabry, "if some countries can unilaterally determine exceptions to the entrenched norm governing unilateral secession, then so can other countries." ${ }^{2}$

Importantly, in its pursuit of diplomatic recognition, Kosovo relied on a number of arguments to support its cause for uncontested statehood: the unique historical circumstances that make Kosovo a sui generis case; the normative grounds for recognition; the ICJ's advisory opinion on the legality of its declaration of independence; and, finally, the achievement of criteria for statehood set out in the Montevideo Convention of 1933. ${ }^{3}$ However, many states are not convinced by the special case of Kosovo, particularly those faced with breakaway moods inside their own borders. While the EU member states have on the whole championed Kosovo's cause, the five members with internal problems of their own - Cyprus, Greece, Romania, Slovakia and Spain - have refrained from recognizing the country. ${ }^{4}$ As for the post-Soviet cases, South Ossetia and Abkhazia have been guided in their quest for international support to a great extent by the geopolitical orientation of countries that may potentially recognize their independent status. Abkhazia, for instance, abandoned its search for understanding among Western European states and eventually turned to other regions instead, focusing on Latin America in particular. As former Minister for Foreign Affairs of the Republic of Abkhazia M. Gvindjia has stated, this was largely due to the prevailing conviction in the West that was interpreted in Abkhazia as follows: "we don't like you, because you are friends with Russia." ${ }^{5}$

\section{Conclusion}

This article focused on the enabling and simultaneously disabling norms and practices regulating the admission of newcomers to the contemporary international system of sovereign states that lead to the emergence of double standards. The current

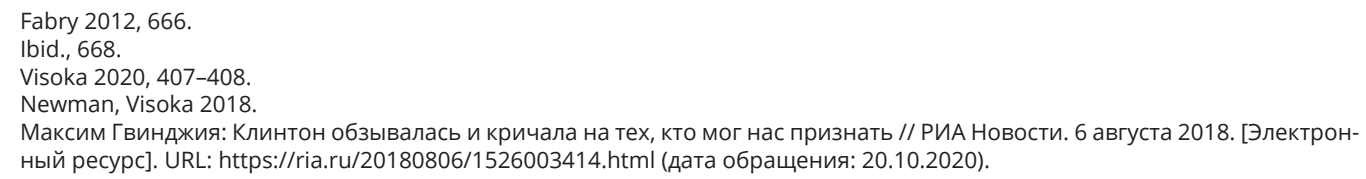

Максим Гвинджия: Клинтон обзывалась и кричала на тех, кто мог нас признать // РИА Новости. 6 августа 2018. [Электронный ресурc]. URL: https://ria.ru/20180806/1526003414.html (дата обращения: 20.10.2020). 
restrictive measures of international recognition however is not a new phenomenon. The exclusive club of sovereign states typically resorts to the untouchable doctrine of territorial integrity because it fears letting new countries into the international arena. For example, European monarchies were initially cautious about recognizing the United States because they were afraid that the revolutionary potential inside the country would be exported elsewhere. As far as they were concerned, the United States was a country of insurgents, "rebels against a lawful monarch."1

We can see the same kind of fear of unstoppable secessions today when peoples in former colonial territories seek self-determination, as well as in the framing of exceptionalism during the wave of recognitions in 2008. The absence of a clear legal framework in international law governing recognition is actually not surprising. One of the main reasons for this is the idea that international law is a reflection of power politics. It is not that power politics matter more than international law; it is rather a question of their close interrelation. As M. Fabry has pointed out, the general pattern has been, "the bigger the disagreements among the powers, the greater the precariousness of recognition." ${ }^{2}$

The practice of international recognition, as this article has attempted to illustrate, is thus historically contingent. More specifically, it is conditional on global responses to particular concerns and circumstances. It is thus contingent on the degree to which the global community agrees on how to address these concerns. The establishment of the right of self-determination for peoples in former colonies during the Cold War era represent a landmark attempt to codify the rules for recognizing states. When there is no global consensus, exceptions are made, which is precisely what happened in the case of the US-led recognition of Kosovo and the subsequent recognition by Russia of South Ossetia and Abkhazia in 2008. Interestingly, while the UN General Assembly Resolution of 1960 has, despite all its confusions and the numerous exceptions in its application, ${ }^{3}$ been increasingly regarded as a guiding principle, the aftermath of 2008 recognitions has been interpreted as "an existential crisis" of the rules of state recognition. ${ }^{4}$ Such interpretations are due to the fact that right and power are viewed separately, as if they are independent from each other, whereas as this article suggested they are mutually constitutive.

The implication of the argument put forward in this article is that, ultimately, there is no significant conceptual difference between the Declaration on the Granting of Independence to Colonial Countries and Peoples that marked the shift from the achievement of effective statehood to eventual independence and the US-led recognition of Kosovo and the Russian recognition of South Ossetia and Abkhazia in 2008. Both show that norms and their enforcement depend on the same logic of right being co-extensive with power, and both reflect a reconfiguration of the balance of powers in the world order. The only question in this context is the extent to which right coincides with power. The incoherence of the norms and practices of state recognition that leads to the emergence of double standards 
is thus a consequence of the inconsistency of right and power. Moreover, this imbalance of right and power is relevant not only for those who seek international recognition, but also, and more importantly, for those who grant this exclusive privilege to be considered an uncontested member in the community of sovereign independent states.

\section{СПИСОК ЛИТЕРАТУРЫ / REFERENCES}

Berg, Eiki. "Re-Examining Sovereignty Claims in Changing Territorialities: Reflections from 'Kosovo Syndrome'." Geopolitics 14, no. 2 (2009): 219-34. https:// doi.org/10.1080/14650040802693473.

Broers, Laurence. "Recognising Politics in Unrecognised States: 20 Years of Enquiry into the De Facto States of the South Caucasus." Caucasus Survey 1 , no. 1 (2013): 59-74. https://doi.org/10.1080/23761199.2 013.11417283.

Buchanan, Allen. "Theories of Secession." Philosophy and Public Affairs 26, no. 1 (1997): 31-61. https://doi. org/10.1111/j.1088-4963.1997.tb00049.x.

Caspersen, Nina. Unrecognized States: The Struggle for Sovereignty in the Modern International System. Cambridge: Polity Press, 2012.

Coggins, Bridget. Power Politics and State Formation in the Twentieth Century: The Dynamics of Recognition. Cambridge: Cambridge University Press, 2014. https:// doi.org/10.1017/CBO9781107239050.

Curley, Edwin. "Kissinger, Spinoza, and Genghis Khan." In The Cambridge Companion to Spinoza, Edited by Don Garrett. Reprint, 315-42. Cambridge: Cambridge Univ. Press, 1997.

Dembinska, Magdalena, and Aurélie Campana. "Frozen Conflicts and Internal Dynamics of De Facto States: Perspectives and Directions for Research." International Studies Review 19, no. 2 (2017): 254-78. https://doi.org/10.1093/isr/vix010.

Evans, Graham, and Jeffrey Newnham. The Penguin Dictionary of International Relations. Penguin Books, 1998.

Fabry, Mikulas. "The Evolution of State Recognition." In Routledge Handbook of State Recognition, edited by Gëzim Visoka, John Doyle and Edward Newman, 37-47. London, New York: Routledge Taylor \& Francis Group, 2020.

Fabry, Mikulas. Recognizing States: International Society and the Establishment of New States Since 1776. 1. publ. Oxford: Oxford Univ. Press, 2010. https://doi. org/10.1093/acprof:oso/9780199564446.001.0001.

Garrett, Don, ed. The Cambridge Companion to Spinoza.

Reprint. Cambridge: Cambridge Univ. Press, 1997.

Geldenhuys, Deon. Contested States in World Politics.

Basingstoke: Palgrave Macmillan, 2009.

Gunter, Michael. "Self-Determination in the Recent Practice of the United Nations." World Affairs 137, no. 2 (1974): 150-65.

Gunter, Michael. "Self-Determination or Territorial Integrity: The United Nations in Confusion." World Affairs 141, no. 3 (1979): 203-16.

Isachenko, Daria. "Transdniestria and Northern Cyprus." In Routledge Handbook of State Recognition, edited by Gëzim Visoka, John Doyle and Edward Newman, 446-57. London, New York: Routledge Taylor \& Francis Group, 2020.

Isachenko, Daria. The Making of Informal States: Statebuilding in Northern Cyprus and Transdniestria. Rethinking Peace and Conflict Studies. London: Palgrave Macmillan UK; Imprint; Palgrave Macmillan, 2012.
Jackson, Robert H. Quasi-States Sovereignty, International Relations, and the Third World. Cambridge: Cambridge University Press, 1994.

Kurtulus, Ersun N. State Sovereignty: Concept Phenomenon and Ramifications. New York: Palgrave Macmillan, 2005. https://ebookcentral.proquest.com/lib/ kxp/detail.action?docID=308155.

Navaro-Yashin, Yael. "Legal/illegal Counterpoints: Subjecthood and Subjectivity in an Unrecognized State." In Human Rights in Global Perspective: Anthropological Studies of Rights, Claims and Entitlements, edited by Richard Ashby Wilson, Jon P. Mitchell, 71-92. London / New York: Routledge, 2003.

Newman, Edward, and Gëzim Visoka. "The European Union's Practice of State Recognition: Between Norms and Interests." Review of International Studies 44, no. 4 (2018): 760-86. https://doi.org/10.1017/ S0260210518000104.

Newman, Edward. "State Recognition in a Transitional International Order." In Routledge Handbook of State Recognition, edited by Gëzim Visoka, John Doyle and Edward Newman, 109-122. London, New York: Routledge Taylor \& Francis Group, 2020.

Ó Beacháin, Donnacha. "Abkhazia and South Ossetia." In Routledge Handbook of State Recognition, edited by Gëzim Visoka, John Doyle and Edward Newman. London, New York: Routledge Taylor \& Francis Group, 2020.

Österud, Öyvind. "The Narrow Gate: Entry to the Club of Sovereign States." Review of International Studies 23, no. 2 (1997): 167-84.

Pegg, Scott. International Society and the De Facto States. Aldershot: Ashgate, 1998.

Ryngaert, Cedric, and Sven Sobrie. "Recognition of States: International Law or Realpolitik? The Practice of Recognition in the Wake of Kosovo, South Ossetia, and Abkhazia." Leiden Journal of International Law 24, no. 2 (2011): 467-90. https://doi.org/10.1017/ S0922156511000100.

Spinoza, Benedict de, and R. H. M. Elwes. A Theologico-Political Treatise and a Political Treatise. New edition. Dover Philosophical Classics. Mineola, N.Y.: Dover, 1951.

van der Wal, G. A. "Spinoza and the Idea of Reason of State." Studia Spinozana: An International and Interdisciplinary Series 1, no. 303 (1985): 275-304.

Visoka, Gëzim, John Doyle, and Edward Newman, eds. Routledge Handbook of State Recognition. London, New York: Routledge Taylor \& Francis Group, 2020.

Visoka, Gëzim. "Kosovo." In Routledge Handbook of State Recognition, edited by Gëzim Visoka, John Doyle and Edward Newman, 402-16. London, New York: Routledge Taylor \& Francis Group, 2020.

Visoka, Gëzim. Acting Like a State: Kosovo and the Everyday Making of Statehood. Interventions. Abingdon: Routledge, 2018. 


\section{Author}

Daria V. Isachenko,

Dr. Phil., Researcher at the Centre for Applied Turkey Studies (CATS) of the German Institute for International and Security Affairs (SWP), Ludwigkirchplatz 3-4, 10719 Berlin. e-mail: daria.isachenko@swp-berlin.org

\section{Additional information}

Received: November 1, 2020. Accepted: December 15, 2020.

\section{Disclosure statement}

No potential conflict of interest was reported by the author.

\section{For citation}

Isachenko, Daria V. "Double Standards of International Recognition: Right vs. Might?" Journal of International Analytics 11, no 3 (2020): 22-34. https://doi.org/10.46272/2587-8476-2020-11-3-22-34 


\title{
Двойные стандарты международного признания: право против мощи?
}

\begin{abstract}
АННОТАЦИЯ
Почему одни государства получают признание, а другим отказывают в этой привилегии?

В данной статье рассматривается логика, лежащая в основе непоследовательности и противоречивости применения стандартов государственности к непризнанным де-факто государствам. Когда речь идет о практике государственного признания, как подчеркивается в статье, это становится не только предметом политики великих держав. Вопрос даже не в том, заслужило ли государство суверенитет и, следовательно, имеет ли оно законное право на международное признание. Вместо этого нормы признания государства лучше понимать как отражение баланса сил в международном порядке, а не как руководящий принцип оценки притязаний на государственность. Центральное место в этом балансе занимает понимание, соответствует ли право силе, и наоборот. Если такой баланс отсутствует, то мы наблюдаем то, что считается двойными стандартами в практике международного признания. Теоретическая основа статьи связана с идеей Баруха Спинозы о том, что право сосуществует с властью. Исходя из этого тезиса в статье показано, что проблема заключается не в несогласованности норм, регулирующих международное признание, а в отсутствии необходимого равновесия между силой и правом для обеспечения универсальной применимости этих норм. Этот

аргумент иллюстрируется рядом примеров реализации права на самоопределение, которое было предоставлено народам бывших колоний в период холодной войны, а также признанием Косова под руководством США, за которым последовало признание Россией

Южной Осетии и Абхазии в 2008 г. В статье показано, что практика международного признания обусловлена глобальным контекстом и зависит от степени согласия держав относительно того, как решать локальные проблемы. Ключевой тезис, выдвинутый в статье, заключается в том, что в конечном счете нет существенной концептуальной разницы между декларацией о предоставлении независимости колониальным странам и народам, которая

ознаменовала переход от достижения эффективной государственности к окончательной

независимости, и волной признания неколониальных случаев 2008 г. В обоих случаях очевидно, что нормы и их применение зависят от одной и той же логики взаимозависимости права и мощи.
\end{abstract}

\section{КЛЮЧЕВЫЕ СЛОВА}

Признание государств, двойные стандарты, международный порядок, де-факто государства, непризнанные государства

\section{Сведения об авторе}

Дарья Васильевна Исаченко,

доктор философии, научный сотрудник Центра прикладных исследований Турции (CATS) немецкого Института международных отношений и безопасности (SWP),

Людвигкирхплац 3-4, 10719 Берлин.

e-mail: daria.isachenko@swp-berlin.org

\section{Дополнительная информация}

Поступила в редакцию: 1 ноября 2020. Принята к публикации: 15 декабря 2020.

\section{Конфликт интересов}

Автор заявляет об отсутствии потенциального конфликта интересов.

\section{Цитирование}

Исаченко, Д.В. Двойные стандарты международного признания: право против мощи? // Международная аналитика. - 2020. - Том 11 (3). - С. 22-34.

https://doi.org/10.46272/2587-8476-2020-11-3-22-34 